\title{
SELECTED ISSUES ON THE PROTECTION OF THE EUROPEAN UNION'S FINANCIAL INTERESTS
}

\author{
ADAM P. CHOCIEJ ${ }^{1}$
}

\begin{abstract}
This study deals with selected issues regarding the protection of the financial interests of the European Union. The protection of the EU financial interest is the responsibility of both Polish and EU institutions. There is no doubt that the coordination of activities of national and EU institutions can contribute to increasing the effectiveness of the protection of EU financial interests. The study presents Polish and EU institutions. The Author focuses predominantly on the actions taken by the Commission, in particular, its specialized body - the European Anti-Fraud Office (OLAF). The activity of law-making, coordination of activities undertaken by member states and activities undertaken jointly by the Commission and the Member States are indicated. The effects of the actions taken have been presented based on available reports. It presents Polish and EU institutions' involvement in combating fraud to the detriment of the Union. Actions taken by the EU institutions and OLAF have been broadly explored, given their particular role. On the basis of the available reports, the Author has responded to the question whether the institutions' current system of protecting the financial interest of the Union is sufficient and whether the actions taken by the institutions set up to counter fraud to the detriment of the Union's financial interests are effective and efficient.
\end{abstract}

Keywords

Financial interest; OLAF; Commission; European Union; financial law JEL Classification: K34, E62, H41

1 Master of Law, graduate from the Faculty of Law at the University of Bialystok. A Court Mediator in Warsaw and Bialystok. Contact email: adam.chociej@consolator.com.pl. 


\section{Introduction}

Protecting the European Union's financial interests is an important goal of the actions taken by bodies and institutions at the level of the EU and national institutions. At the outset, however, it should be noted that the financial interests of the European Union are not always the financial interests of individual Member States. It should also be borne in mind that the notion of the European Union's financial interest is not tantamount to the concept of the European Union interest.

The EU's interest is undoubtedly a broader concept than the notion of the Union's financial interest ${ }^{2}$. The financial interest of the Union cannot be considered as a sum of the financial interests of individual Member States, in view of the fact that at the national level the financial interest of a State is not the sum of the interests of its citizens (Woltanowski, Kosińska, 2014). There may be a situation where the financial interests of Poland will not fully coincide with the financial interest of the European Union. In this context, it is very important that the Member States, at the stage of setting the financial framework for particular financial perspectives, can express their expectations, and in the course of the negotiations, reach a compromise which will make the assumptions about the Union budget to be coincident with the interests of individual Member States.

According to Art. 317 of the Treaty on the Functioning of the European Union, the European Union budget shall be implemented by the Commission in cooperation with the Member States. Article 325 imposes on both - the Union and the Member States - the obligation to fight fraud and any other illegal activity affecting the financial interests of the Union; wherein the Member States combating fraud affecting the Union's financial interests, shall take the same measures they undertake to combat fraud violating their own financial interests.

It should be stressed here that the bodies of the Member States account for around $80 \%$ of the expenditure of the whole European Union (Commission: COM(2016) 472). The functioning of the supervisory system in each Member State should be an effective element of an effective anti-fraud counteraction. At the same time, it is equally appropriate to coordinate the actions of the institutions responsible for counteracting and combating abuse against the EU, both on EU and national level, which is equally important in the effective fight against fraud. In recent years, the European Commission has taken a number of measures to ensure the most effective

2 It can be acknowledged that it is in the interest of the Union to, above all, implement the objectives of the Union. In the original wording of the Treaty on European Union of 7 February 1992, Art. B, the stated Union's objectives are: promoting balanced economic progress, implementing the common foreign and security policy, developing close cooperation in the field of justice and home affairs. The Lisbon Treaty has changed the original wording of the article, and currently, in Art. 3/1 of the Treaty, it is stated that the purpose of the Union is to promote peace, its values and the prosperity of its people. 
protection of the EU financial interest, which will be analyzed in the further part of this paper. Before presenting the activities of the European Commission, it seems important to at least briefly present EU and Polish institutions responsible for the protection of the financial interests of the European Union.

\section{Institutional System for the Protection of the Financial Interests of the European Union}

The most important European institutions participating in the audit of the implementation of the European Union budget and, as a consequence, counteracting the actions adversely affecting the financial interests of the European Union are European Commission, European Court of Auditors (ECA) as well as European Anti-Fraud Office (OLAF). OLAF is in this context a particular institution. As a part of the European Commission, it has total independence in the exercising of its investigative function.

In Poland the institution responsible for protecting the financial interests of the European Union is primarily the Ministry of Finance. Control of the correct use of EU funds and, as a result, the detection of irregularities detrimental to the financial interests of both the European Union and Poland, is carried out by several institutions at various stages. The Supreme Audit Chamber plays the most important role and is subordinated to the Ministry of Finance National Tax Administration (pl. Krajowa Administracja Skarbowa) ${ }^{3}$ (Act of 16 November 2016). Important role plays also controls carried out by the managing authorities (Regulation (EU) no. 1303/2013). In cases of violation of public finance discipline Arbitration Committees also play an important role ${ }^{4}$.

3 Prior to 1 March 2017, i.e. before the Act of 16 November 2016 of the National Tax Administration Act came into force, in the Polish legal system, the Tax Inspectorate (pl. Urząd Kontroli Skarbowej), the Tax Offices (Urzędy Skarbowe) and the Customs Offices (pl. Urzędy Celne) were primarily responsible for the detection of irregularities and actions against the financial interests of the EU. On the date of entry into force the Act of the National Tax Administration, their competence were taken over by the bodies of the National Tax Administration.

4 The bodies adjudicating at first instance on cases of violation of public finance discipline are the following: 1) Joint Arbitration Committee (Wspólna Komisja Orzekająca); 2) Arbitration Committee attached to Head of the Prime Ministers' Office (Komisja Orzekająca przy Szefie Kancelarii Prezesa Rady Ministrów); 3) Interministerial Adjudicating Committee attached to the Minister in charge of Public Finances (Międzyresortowa Komisja Orzekająca przy Ministrze właściwym do Spraw Finansów Publicznych); 4) Interministerial Adjudicating Committee attached to the Minister in charge of Public Administration (Międzyresortowa Komisja Orzekająca przy Ministrze właściwym do Spraw Administracji Publicznej); 5) Interministerial Adjudicating Committee attached to the Minister of Justice (Międzyresortowa Komisja Orzekająca przy Ministrze Sprawiedliwości); 6) Regional Adjudicating Committees attached to the Regional Accounting Chambers (Regionalne Komisje Orzekające przy Regionalnych Izbach Obrachunkowych); The Court adjudicating in cases of breach of discipline in public finance of the second instance is the Chief of the Judicial Commission in Cases of Violation of the Public Finance Discipline. 
The European Commission prepares the annual accounts of the European Communities. It also carries out internal audits as well as controls the implementation of budgets in the Member States. The European Commission requires the Member States to have efficient management and control systems for spending funds from the Union. The Commission may carry out checks in the Member States, including random checks of operations financed by EU funds as well as checks on the management and control systems in the Member States.

The main task of the European Court of Auditors is to monitor the implementation of the European Union budget, i.e. the regularity and legality of all Union expenditure and financial management. ECA auditors conduct audits both in European institutions and in Member States (also in countries receiving EU assistance). The ECA draws up its annual activity reports (Treaty on the Functioning of the European Union - consolidated version, Art. 287/4).

The task of the European Anti-Fraud Office (OLAF) is to detect fraud, misappropriation of subsidies and tax evasion, as well as fighting against corruption and any illegal activities that interfere with the interests of the Union. Although OLAF is functioning within the structure of the European Commission, it is necessary, in context of the specific nature of its activities, to isolate OLAF's investigations and actions taken to protect the financial interests of the European Union.

It is worth stressing out that Poland was still in the process of negotiating before joining the European Union, and has committed to implementing the EU acquis in the field of counteracting fraud against the EU financial interests. On 1 July 2003 the Government Plenipotentiary for Combating Financial Irregularities against Poland and EU (pl. Petnomocnik Rzadu Do Spraw Zwalczania Nieprawidtowosci Finansowych na Szkode Rzeczypospolitej Polskiej lub Unii Europejskiej) was appointed by the Council of Ministers to the Harmony of the Republic of Poland or the European Union (Regulation of the Council of Ministers of 1 July 2003).

The tasks of the Government Plenipotentiary for Combating Financial Irregularities against Poland and EU include, in particular, the initiation, coordination, and implementation of activities aimed at securing the financial interests of the Republic of Poland and the European Union. The Plenipotentiary in particular coordinates activities of governmental authorities in this regard and ensures the proper flow of information between them. He is also responsible for reporting to the European Commission on irregularities in the use of EU funds and, collects, verifies and analyzes the documents and information necessary for their preparation. The plenipotentiary may also initiate and carry out work on the preparation of legal acts in the field of the protection of the Union's financial interests. 
Selected Issues on the Protection of the European Union's Financial Interests

Government Plenipotentiary for Combating Fraud against Poland and EU is the Head of Interdepartmental Team for Combating Fraud against Poland and EU the auxiliary body of the Council of Ministers. The team plans, coordinates and monitors activities related to the EU financial interests by the governmental administration bodies, develop proposals for effective exchange of information between administration bodies in order to improve prevention actions and combating breaches of the EU financial interests.

Both the Plenipotentiary and the Interdepartmental Team provide technical and office assistance to the Public Finance Department at the Ministry of Finance.

The Public Finance Department, in addition to the Government Plenipotentiary and the Interministerial Group, also carries out auditing and controls tasks for EU funds and non-reimbursed funds from other sources, as well as plays an important role in combating fraud against the financial interests of the EU - The Anti-Fraud Coordination Service (AFCOS), in cooperation with the European Anti-Fraud Office (OLAF) (Regulation (EC, Euratom) no. 883/2013).

\section{European Commission}

The European Commission to prevent fraud at EU level undertakes a series of actions at various levels (Commission: $\operatorname{COM}(2015)$ 386; Commission: $\operatorname{COM}(2016)$ 472). Most actions directly or indirectly contribute to closer cooperation between the Member States and better coordination of actions aimed at counteracting and preventing fraud to the detriment of the financial interests of the European Union. The most important actions of the Commission in this area include:

- Initiative for change in the legal system of the European Union,

- Fighting corruption in the European Union,

- Combating fraud related to the revenue of the European Union.

\subsection{Initiatives for Changes in the Legal System of the European Union}

The most important initiatives of the European Commission include working on improving and harmonizing the prosecution of crimes against the financial interests of the European Union on the basis of criminal law. As early as 2014, at the initiative of the European Commission, two proposals were made by the European Parliament and the Council to improve the effectiveness of criminal law with regard to the protection of EU financial interests (Commission: $\mathrm{COM}(2015) 386$ ): 
- the proposal of a directive on the protection of EU financial interests enabling the fight against fraud through criminal law;

- the draft regulation on the establishment of the European Public Prosecutor's Office.

Between 2015 and 2016, the proposed legal arrangements were agreed with the Member States. On 25 April 2017, the Council of Europe adopted a directive on the protection of EU financial interests (European Council Press Release of 25 April 2017 no. 209/17), previously agreed with EU governments. The adopted project predicted custodial sentences for serious frauds to the detriment of the EU budget, including VAT. This directive has yet to be approved by the Member States and the European Parliament.

The European Prosecutor's Office was stipulated in the treaties already in 2009 but has not been established to date. On 9 February 2017, the Council of Europe ran unanimously for the proposed regulation establishing the European Public Prosecutor's Office (European Council Press Release of 7 February 2017, no. 48/17). Due to the lack of unanimity in the Council, 16 Member States ${ }^{5}$ announced their intention to step up their cooperation in order to establish a European Public Prosecutor's Office (European Council Press Release of 3 April 2017, no. 184/17), so that the negotiations on the final version of the Regulation could be resumed in the Council. On 5 October 2017, the European Parliament approved the creation of a European Public Prosecutor's Office on the basis of enhanced cooperation ${ }^{6}$.

\subsection{Combating Corruption in the European Union}

In the European Commission report from 3 February, 2014 on combating corruption in the EU (Commission: COM (2014) 38) The Commission focused on corruption in the public procurement. This was the first report prepared by the Commission to which it was obliged, based on the EU anti-corruption mechanism introduced in 2011, based on Art. 83 of the Treaty on the Functioning of the European Union. The report contained the description of trends and developments in corruption and methods to counter corruption in the Member States. The report of the Commission has been criticized by the European Court of Auditors (www.eca.europa.eu), as based on the results of Member States' perceptions of corruption and not on analyzes and findings. This study was also criticised for excluding the institutions and bodies of the European Union from the analysis. Justified seemed the European

5 Belgium, Bulgaria, Croatia, Cyprus, Finland, France, Greece, Spain, Lithuania, Luxembourg, Germany, Portugal, Czech Republic, Romania, Slovakia, and Slovenia.

6 Poland, Denmark, the Netherlands, Ireland, Malta, Sweden, the United Kingdom and Hungary didn't join the European Prosecutor's Office. 
Selected Issues on the Protection of the European Union's Financial Interests

Court of Auditors critique of this document - of not including reporting to the EU institutions, and postulating the extension of the next report by the details available from OLAF European Commission.

Among the Commission's initiatives, the Hercules III program operation in years 2014-2020, should also be mentioned (Regulation (EU) no. 250/2014). This program aims to promote anti-fraud measures against the interests of the Union in the Member States. It is a continuation of the Hercules II program, which ran from 2007 to 2013. The program includes training and conferences to exchange experiences between the Member States and to strengthen cooperation in the fight against fraud. Within the project, technical resources for anti-fraud institutions to the detriment of EU financial interests are purchased.

\subsection{Combating Fraud Related to Revenue and Expenditure of the European Union}

The actions of the European Commission aimed at protecting the Union's financial interests in the field of EU income include, in particular, measures to improve the flow of information between the Member States and mutual assistance in matters relating to customs operations, agricultural law and VAT fraud.

At the initiative of the Commission on 9 September 2015, was adopted the Regulation of the European Parliament and of the Council (Regulation (EU) no. 2015/1525). This regulation anticipates the creation of a centralized database on containers and goods imported, exported and transited through the European Union (Regulation (EU) no. 2015/1525, Art. 1/1). The introduced regulation should make the analysis of the data considerably easier and therefore more effective for both the national customs authorities and OLAF.

At the initiative of the Commission, the Anti-Fraud Information System (AFIS) has been adopted. The term is defined as an application system that enables the timely and secure exchange of information about fraud, as well as the storage and analysis of such data. By 2015, the system had more than 8,000 registered users acting on behalf of over 1700 institutions in the Member States, Commission departments and other EU bodies (Report $\operatorname{COM}(2016)$ 472: 11). This centralized system of information helps to prevent fraud against the financial interests of the Union, both the customs authorities of the Member States and to OLAF entities, it also enables joint customs operations.

The joint customs operations undertaken by the Commission are coordinated by OLAF and will be analyzed in the OLAF part of this paper. In the Commission's annual report to the European Parliament - Fight against fraud for the year 2015 
- the Commission set up the Member States' experience of VAT fraud, pointing out that there is a common impediment to the investigation of transaction chains in the presence of third-country operators (Commission: COM(2016) 472: 13). To assist the national authorities, the Commission, together with the Member States, is exploring the possibility of improving the functioning of Eurofisc so that VAT fraud schemes are detected faster than before (Commission: COM(2016) 472: 13). Commission initiatives to eliminate fraud while spending EU funds are primarily legislative initiatives designed to monitor the spending of these funds in the Member States and to report any irregularities.

In 2015, the Commission adopted 4 Delegated Regulations and 4 Implementing Regulations on rules for reporting financial irregularities using EU funds for 20142020 (Commission: (EU) 2015/1970; Commission: (EU) 2015/1971; Commission: (EU) 2015/1972; Commission (EU) 2015/1973; Commission: (EU) 2015/1974; Commission: (EU) 2015/1975; Commission: (EU) 2015/1976, Commission: (EU) 2015/1977). Thanks to the introduced reporting system, many abnormalities in the use of EU funds are being detected on the level of verification of payment applications by the National Managing authorities of the EU programs.

\section{European Anti-Fraud Office (OLAF)}

The European Anti-Fraud Office (OLAF) was established on 28 April 1999 (Commission: (1999/352/EC, ECSC, Euratom)). OLAF is the only EU body Authorized to investigate fraud and abuse of EU funds. During the initial period of operation, OLAF primarily provided assistance in conducting investigations to the authorities of the Member States as well as, to a lesser extent, conducting independent investigations. In 2006 for the first time, the number of OLAF investigations was equal to the number of investigations in which it provided assistance.

The tasks of OLAF were defined in Art. 2 of the Commission Decision from 28 April 1999 establishing the European Anti-Fraud Office (current wording of art 2 was implemented on the basis of Commission Decision (2013/478/EU) and Commission Decision (EU) 2015/2418). According to Art. 2 OLAF's tasks include in particular external and internal investigations to protect the financial interests of the Union.

External investigations are aimed at combating corruption, fraud and other illegal activities detrimental to the financial interests of the Union, as well as the activities of economic operators run in breach of EU law. 
Selected Issues on the Protection of the European Union's Financial Interests

OLAF's internal investigations occur within the Union's bodies and are aimed at combating fraud, corruption as well as violations by officials and employees of EU bodies. Internal investigations, if infringements are found, may be effective in initiating criminal or disciplinary action against EU officials.

OLAF may investigate violations of the Union financial interest in respect of all Union expenditures (in particular under the Structural Funds, agricultural policy, rural development), Union revenues (mainly customs duties and VAT revenues), and suspicion of irregularities in the work of the staff and officials of the European Union.

According to Art. 2, The Office's tasks outside the scope of investigations should also include:

- Assisting the Commission in dealing with the Member States to counter and fight against fraud.

- Developing concepts and strategies to combat fraud. This goal is achieved in particular through participation in a variety of international initiatives, actions undertaken by institutions and associations to fight fraud and corruption, the promotion of exchange of experience and best practices.

- Preparing legislative and executive initiatives for combating fraud and corruption.

- Preparing all operational activities of the Commission, in particular by developing appropriate infrastructure, collecting and analyzing information, providing technical support to national authorities, and supporting national authorities in the education and training of staff.

OLAF's investigation procedure is regulated by Regulation of the European Parliament and of The Council of 11 September 2013 concerning investigations conducted by the European Anti-Fraud Office (OLAF) (Regulation (EU, Euratom) no. 883/2013). Regulation in Art. 2/1 defines a concept Financial interests of the Union "as it shall include revenues, expenditures, and assets covered by the budget of the European Union and those covered by the budgets of the institutions, bodies, offices and agencies and the budgets managed and monitored by them".

The Regulation, as well as the Commission Decision from 28 April 1999 (Commission: (1999/352/EC, ECSC, Euratom)), divides OLAF's investigations into external and internal ones. The Regulation regulates the procedures for initiating investigations, the investigation procedure and it Authorizes OLAF to exchange information between the competent authorities of the Member States. It also Authorizes OLAF to cooperate with Eurojust and Europol (Art. 13). 
The regulation also monitors the internal organization of the Office. OLAF is headed by a Director-General appointed by the Commission for a seven-year term (Art. 17/1). OLAF's investigative tasks are monitored by the Supervisory Committee, consisting of five independent members elected for a five-year term?

According to the OLAF activity report for 2016, OLAF employees considered 1157 cases reported to the office as abusive. On the basis of these notifications, 219 inquiries were opened in 2016 (Olaf Report, 2016: 12). At the same time, the Office also issued 346 recommendations to the Member States to recover funds totaling $€ 631.1$ million. It should be noted here that the issue of OLAF's recommendation is not consistent with the recovery of funds by a Member State. OLAF reports for 2015 and 2016 did not include information on what actually had been recovered on the basis of the recommendations issued, which seems to be an important element in the assessment of OLAF's activities.

Expenditure on OLAF's operation in 2016 amounted to over $€ 58$ million, of which $€ 40.5$ million was spent on staff salaries. This is a slight increase compared to 2015 , with personnel expenditure of $€ 39$ million ( $€ 57.7$ million in total) (OLAF Report, 2015: 37).

OLAF's investigations which ended in 2016 covered all areas related to EU expenses. For example, out of 344 investigations completed in 2016, 69 were related to Structural Funds, 52 to external assistance and 48 to staff and Union officials (OLAF Report, 2016: 14). Those investigations were related to, among others: public procurement, EU spending on research and development and personnel employed in EU institutions.

A very important element of OLAF's activity is coordination and cooperation with the Member States in joint customs operations (JCOs). The joint customs operations are coordinated actions performed by the customs authorities of individual states to combat the illicit trade of goods. OLAF provides intelligence, technical and financial support for JAFs, and enables the secure exchange of information (eg. using the AFIS platform) (Report COM(2016) 472 from the Commission to the European Parliament: 12).

In 2015, OLAF conducted seven joint customs operations (JCO) (Ibid):

- JCO JETSTREAM - joint operation coordinated by the French Customs Service. The aim to detect illegal trade in the Atlantic Ocean. The action resulted in the seizure of over several tons of hashish transported by sea. working in high-level positions in judicial or investigative bodies. Members of the Committee are appointed by common accord of the European Parliament, the Council and the Commission. 
- JCO JUPITER - The aim of this operation was to combat illicit transport and trade in sensitive goods in the Mediterranean. The operation was coordinated by the Spanish Customs Service.

- JCO FRANKSTEAD - operation organized and run by the customs authorities of Germany and the United Kingdom aimed at combating drug trafficking.

- JCO SASHA - operation organized and coordinated by the French customs authorities. The aim of this action was to combat smuggling and the trade of chemical drug precursors. Most of the EU member states participated in the operation, which was supported by the services of EUROPOL. As a result of the activities, approximately $185 \mathrm{~kg}$ of illegal substances were seized.

- JCO BALTICA - directed and coordinated by OLAF and the Polish customs authorities. Six European countries (Estonia, Latvia, Lithuania, Poland, Finland, and Sweden) and EUROPOL participated in this operation. Its aim was to fight the smuggling of cigarettes from the Russian Federation and Belarus to the European Union. As a result of the activities carried out, around 13 million illegally transported cigarettes were seized by Customs services.

- JCO HANSA - operation organized by the UK Customs Service and Europol to combat the illegal movement of excise goods, particularly cigarettes. OLAF participated in this operation and provided a secure information exchange system.

- JCO ROMOLUK II - operation organized by OLAF and the Romanian customs authorities. Moldovan and Ukrainian customs services were involved in the operation as well, and its aim was to inspect consignments sent to the European Union by road and rail. The operation resulted in the seizure of over 3.8 million cigarettes and about 100 liters of alcohol.

Data on the effects of Joint Customs Operations (JCO) included in the Commission's Annual Report and the OLAF Annual Report for 2015 is very laconic. It is difficult to assess whether the joint operations carried out with the enormous involvement of customs services from many countries brought real and measurable results, and above all, what effect it had on the financial resources involved.

In 2016, OLAF co-organized or supported 12 joint customs operations, 4 of which were organized in cooperation with the Member States and financed by OLAF (The Olaf Report 2016: 24):

- JCO MAGNUM - operation coordinated by the customs authorities of Estonia. Its purpose was to fight the smuggling of tobacco products by land 
from Russia, Belarus, and Ukraine. This operation resulted in the seizure of about 11 million cigarettes.

- JCO WAREHOUSE III - operation coordinated by the customs services of Finland to combat the smuggling of excise goods, in particular, mineral oils and fuels, as well as avoidance of tax obligations. The operation involved 26 Member States and Europol and it resulted in the acquisition of several thousand liters of diesel.

- JCO ORION - the operation was coordinated by the Greek Customs Services, and was aimed at fighting non-EU goods entering the European market with the omission of customs duties and VAT. This operation was managed by the OLAF Permanent Operational Coordination Unit, involving 23 Member States and Europol. It helped to identify cases of underestimation of the objects which were a subject to customs declaration.

- JCO Wafers - operation coordinated by the customs services of the Kingdom of the Netherlands. Its purpose was to counter the import of counterfeit semiconductors and other counterfeit products into the EU from China and Hong Kong. It was conducted in cooperation with Europol and the industry representatives and led to the acquisition of several hundred thousand counterfeit semiconductors and other non-original products.

Reports on both - joint customs operations conducted in 2015, as well as OLAF operations, lack information on the value of detected irregularities or the value of detected irregularities in relation to the expenditure incurred for detecting them.

In the data published in the OLAF report, however, there is information about the number of cigarettes seized in connection with the anti-trafficking operations. About 68 million cigarettes were disposed of in 2013, 132 million in 2014, 17 million in 2015 and 201 million in 2011.

Attention is drawn to the fact that after the very effective year 2014, the number of smuggled cigarettes fell nearly tenfold within the next two years. It would be appropriate for the Commission and OLAF to respond to the question of why such significant reductions in the detection of smuggled cigarettes occurred, despite the considerable involvement of the customs services of various countries and the coordination of OLAF activities 8 . Another question, to which is difficult to find the answer in the documents and reports of both the Commission and OLAF, is the question about the commensurability of the financial resources and human resources involved and the financial effects achieved. cigarettes was noticed, while more non-branded cigarettes were smuggled. This is not the answer to the question of reducing the detection of cigarette smuggling. 


\section{Conclusions}

When analyzing both - the European Commission and OLAF's annual reports, it can be said that numerous actions are undertaken to protect the EU financial interest. Existing legislation at the EU level not only obliges the Commission, OLAF, and the Member States to protect the financial interests but also establishes tools to protect them. It seems that the problem of protecting the Union's interest is not in the field of tools. Both the Commission and OLAF have tools to protect them and the problem seems to lie elsewhere.

Firstly, the coordination of activities undertaken by the member states is becoming ever more important. Fraudulent acts of the Union are more often of international nature. Without proper coordination of actions in different countries, the fight against fraud can be very difficult and ineffective. This aspect seems to be particularly important when taking into account the joint customs operations, but also in the fight against the increasing gap in VAT payments.

Secondly, as it is often highlighted in the Commission reports, Member States report delays in the detection of financial irregularities. The Commission documents often contain information that the reporting system is very heterogeneous, making it difficult to monitor both Member States' actions and their effectiveness (European Parliament resolution of 11 March 2015).

Thirdly, the effectiveness of Member States' enforcement of the recommendations issued by OLAF and the Commission appears to be a big issue ${ }^{9}$ (European Parliament Resolution of 11 March 2015: 22). OLAF reports contain information on the amount and value of recommendations made during the course of the proceedings, but they lack information on its effectiveness. It seems necessary to harmonize the information provided by the Member States in order to assess the effectiveness of Member States actions.

In the context of the actions taken by the Commission and in particular by OLAF, it seems reasonable to question the effectiveness of EU expenditure on OLAF's functioning. Without questioning the legitimacy of OLAF's operation, it is possible to raise the question of the amount of expenditure incurred for OLAF's staff, which in 2016 amounted to more than $€ 40$ million (while OLAF's technical infrastructure and IT networks were over $€ 10$ million) obtained by the Union through its functioning. It is difficult to assess the rationality of spending on OLAF's functioning without having full information about the actual size of the financial benefits resulting from its functioning. This data could help to assess the relevance

9 For example, in the agriculture and rural development area, an amount of $€ 197$ million was recovered, while at the end of $2013 € 1318$ million were recovered. 
of the EU initiative on the establishment of the European Public Prosecutor's Office. Analyzing the benefits resulting from its possible appointment should also evaluate this initiative from the perspective of its operating costs.

\section{References}

Woltanowski, P., Kosińska, R.: Granice ochrony praw podatnika w świetle orzecznictwa Trybunału Konstytucyjnego (Limits of protection of the taxpayer's right in the light of the case law of The Constitutional Court), in: Wójcicka, E. (ed.): Ochrona praw i wolność jednostki wobec władczej ingerencji administracji publicznej - stan obecny i wyzwania (Protection of rights and individual's freedom against imperious interference of public administration - current status and challenges), Częstochowa: Akademia im. Jana Długosza, 2014.

EU: Treaty on the Functioning of the EU no. OJ 2016/C 202.

EU: Commission Decision no. 1999/352/EC, establishing the European Anti-fraud Office.

EU: Commission Decision no. 2013/478/EU, amending Decision 1999/352/EC, ECSC, Euratom establishing the European Anti-fraud Office.

EU: Commission Decision no. 2015/2418, European Anti-fraud Office.

EU: Council Regulation (Euratom) no. 1074/1999, concerning investigations conducted by the European Anti-Fraud Office.

EU: Regulation no. 1073/1999 of the European Parliament and of the Council, concerning investigations conducted by the European Anti-Fraud Office.

EU: Commission Delegated Regulation no. 2015/1970, supplementing Regulation no. 1303/2013 of the European Parliament and of the Council with specific provisions on the reporting of irregularities concerning the European Regional Development Fund, the European Social Fund, the Cohesion Fund, and The European Maritime and Fisheries Fund.

EU: Commission Delegated Regulation no. 2015/1971, supplementing Regulation no. 1306/2013 of the European Parliament and of the Council with specific provisions on the reporting of irregularities concerning the European Agricultural Guarantee Fund and the European Agricultural Fund for Rural Development and repealing Commission Regulation no. $1848 / 2006$.

EU: Commission Delegated Regulation no. 2015/1972, supplementing Regulation no. 223/2014 of the European Parliament and of the Council with specific provisions on the reporting of irregularities concerning the Fund for European Aid to the Most Deprived.

EU: Commission Delegated Regulation no. 2015/1973, supplementing Regulation no. 514/2014 of the European Parliament and of the Council with specific provisions on the reporting of irregularities concerning the Asylum, Migration and Integration Fund and the instrument for financial support for police cooperation preventing and combating crime, and crisis management.

EU: Commission Implementing Regulation no. 2015/1974, setting out the frequency and the format of the reporting of irregularities concerning the European Regional Development Fund, the 
European Social Fund, the Cohesion Fund and the European Maritime and Fisheries Fund, under Regulation no. 1303/2013 of the European Parliament and of the Council.

EU: Commission Implementing Regulation no. 2015/1975, setting out the frequency and the format of the reporting of irregularities concerning the European Agricultural Guarantee Fund and the European Agricultural Fund for Rural Development, under Regulation no. 1306/2013 of the European Parliament and of the Council.

EU: Commission Implementing Regulation no. 2015/1976, setting out the frequency and the format of the reporting of irregularities concerning the Fund for European Aid to the Most Deprived, under Regulation no. 223/2014 of the European Parliament and of the Council.

EU: Commission Implementing Regulation no. 2015/1977, setting out the frequency and the format of the reporting of irregularities concerning the Asylum, Migration and Integration Fund and the instrument for financial support for police cooperation, preventing and combating crime, and crisis management, under Regulation no. 514/2014 of the European Parliament and of the Council.

EU: Council Regulation no. 1083/2006, laying down general provisions on the European Regional Development Fund, the European Social Fund, and the Cohesion Fund and repealing Regulation no. 1260/1999.

EU: Regulation no. 883/2013 of the European Parliament and of the Council of 11 September 2013 concerning investigations conducted by the European Anti-Fraud Office (OLAF) and repealing Regulation no. 1073/1999 of the European Parliament and of the Council and Council Regulation no. 1074/1999.

EU: Regulation no. 1303/2013 of the European Parliament and of the Council, laying down common provisions on the European Regional Development Fund, the European Social Fund, the Cohesion Fund, the European Agricultural Fund for Rural Development and the European Maritime and Fisheries Fund and laying down general provisions on the European Regional Development Fund, the European Social Fund, the Cohesion Fund and the European Maritime and Fisheries Fund and repealing Council Regulation no. 1083/2006.

EU: Regulation no. 250/2014 of the European Parliament and of the Council, establishing a program to promote activities in the field of the protection of the financial interests of the European Union (Hercule III program) and repealing Decision no. 804/2004/EC.

EU: Regulation no. 2015/1525 of the European Parliament and of the Council, amending Council Regulation no. 515/97 on mutual assistance between the administrative authorities of the Member States and cooperation between the Member States and the Commission to ensure the correct application of the law on customs and agricultural matters.

EU: European Parliament Resolution no. 2014/2155 (INI), on the 2013 Annual Report on the protection of the European Union's financial interests - Fight against fraud.

PL: Act of 16 November 2016, on National Tax Administration, as amended.

PL: Regulation of the Council of Ministers of 1 July 2003, on the Government Plenipotentiary for the Combating of Financial Irregularities for the Harmonization of the Republic of Poland or the European Union. 
PL: Regulation no. 58 of the President of the Council of Ministers of 19 August 2010 on the Interdepartmental Team for Combating Financial Irregularities for the Harmonization of the Republic of Poland or the European Union. www.bip.kprm.gov.pl.

PL: Ordinance of the Minister of Development and Finance of 3 March 2017, on the establishment of organizational regulations of the Ministry of Finance.

EU: Report COM(2014) no. 38 from The Commission to The Council and the European Parliament EU Anti-Corruption Report.

EU: Report $\operatorname{COM}(2015)$ no. 386 from the Commission to the European Parliament and the Council Protecting the European Union's Financial Interests - Fight against fraud 2014 - Annual Report.

EU: Report COM(2016) no. 472 from the Commission to the European Parliament and the Council Protecting the European Union's Financial Interests - Fight against fraud 2015 - Annual Report.

European Court of Auditors' View on the Commission's Report on Anti-Corruption Measures. www. eca.europa.eu.

European Council Press Release of 07 February 2017 no. 48/17. www.consilium.europa.eu.

European Council Press Release of 03 April 2017 no. 184/17. www.consilium.europa.eu.

European Council Press Release of 25 April 2017 no. 209/17. www.consilium.europa.eu.

OLAF Report 2014. www.ec.europa.eu.

OLAF Report 2015. www.ec.europa.eu.

OLAF Report 2016. www.ec.europa.eu. 